\author{
Piotr Pieczonka \\ adwokat, Gdańsk \\ pieczonka@kpnp.pl \\ ORCID: https://orcid.org/0000-0001-5029-0649
}

\title{
Social packages of a normative nature and their interpretation
}

http://dx.doi.org/10.12775/SIT.2018.037

\section{Social packages of a normative nature}

In Polish legal system there is no legal definition of a social package. Due to the lack of a statutory definition and the wide variety of social packages at the level of workplaces, which results in heterogeneity of such agreements, we are forced to search for the definition and nature of such agreements by referring to typology, divisions and classification to which the most common packages concerning mutual relations between employers and employees are subjected in practice. At the same time, in the absence of a legal definition and norms of universally binding law directly related to this type of agreements, it becomes necessary to seek legal basis allowing for conclusion of social packages at the level of workplaces and regulating the enforcement of rights and obligations arising therefrom. Determining legal nature of social packages is important not only for the admissibility of deriving individual employee claims from their provisions, but also, and perhaps first and foremost, for the manner and technique of interpretation of their provisions.

Pursuant to labor law social packages can be understood in a broad or narrow way, thus constituting two separate types of 
collective agreements ${ }^{1}$. Social packages, in the broad sense, are acts of a general nature, concluded by social partners with the participation of public authorities, designed to indicate broad lines of economic and social policy aimed at achieving specific social objectives. On the other hand, social packages in the narrow sense are packages concluded by the parties to an employment relationship, whose aim is to determine specific aspects of broadly understood contents of employment relationships ${ }^{2}$.

In the further part of this article I will refer only to social packages in the narrow sense of the term, because only such packages may, in principle, be a source of rights and obligations of the parties to employment relationships. It should be emphasized that, in the literature on the subject and in the case law, the notion of "social package", or "social agreement" does not have a uniform meaning or legal character. As I signaled at the beginning, the issue of social packages under labor law has not yet been discussed in more detail in literature. In doctrine, with regard to the concept of "collective agreements", two different views are presented. The first of them, presented, among others, by Bogusław Cudowski, divides "collective agreements" into packages in the strict sense of the word, i.e. those concluded by trade unions with the employer (employers' organization), concerning collective rights or interests of employees, and the so-called unnamed collective packages of labor law. A different view is presented by Walerian Sanetra, who believes that collective packages can be concluded not only by trade unions and employers, and that collective packages also include acts established and adopted by way of an agreement, reconciliation or after consulting the other social partner ${ }^{3}$.

Kazimierz Jaśkowski defines social packages as agreements between social partners, concerning individual and collective rights

${ }^{1}$ More on: Z. Salwa, Collective agreements as a source of labor law, in: W. Sanetra. Labor law. On current issues, Białystok 1999, p. 25.

${ }^{2}$ Z. Salwa, Collective agreements, p. 25; E. Kieś, "Collective agreements worsening the conditions of work performance", doctoral dissertation, Katowice 2013, p. 18.

${ }^{3}$ See: E. Kieś, “Collective agreements”, pp. 18-19. 
and obligations of employees and employers ${ }^{4}$. Such packages may concern mutual obligations of the parties to the agreement (the obligatory part of the agreement), to which civil law provisions apply, while the essential part of collective packages consists, however, in definition of the employer's obligations towards the employees who are its beneficiaries, and, occasionally, also in specification of the employees' obligations arising from higher-order acts (the normative part of the agreement).

Social packages, as one of the types of collective packages, are concluded by social partners. The collective nature of the agreement is determined by the parties to the agreement, at least one of whom, particularly the employee, should have a collective characteristic ${ }^{5}$. Social dialogue partners are workers represented by trade unions or by their representatives, and employers or employers' organizations ${ }^{6}$. The Constitution of the Republic of Poland directly grants social partners (in particular trade unions, employers and their organizations) the right to conclude social agreements. Social packages, in the narrow sense of the term, undoubtedly fall within the category of other packages listed in Article 59, paragraph 2 of the Constitution, and entities so indicated (including employers) are social partners within the meaning of Article 20 of the Constitution. The Supreme Court ruled, on 7 December 2012, that the ratio legis of the provision of Article 59 paragraph 2 of the Constitution constitutes a guarantee, to social partners, of their right to conclude any collective agreements ${ }^{7}$. Doubts are raised by Article 59 paragraph 2 of the Constitution, as to the way in which it identifies social partners on the employees' side. As Monika Gładocha points out, the problem results from different interpretations of this provision, as it only refers to trade unions as entities with specific guarantees in the collective labor law. According to this author,

${ }^{4} \mathrm{~K}$. Jaśkowski, Collective agreements in labor law, in: Individual and collective labor law, ed. L. Florek, Warsaw 2007.

${ }^{5}$ See G. Goździewicz, Nature of Collective Agreements in Labor Law, Warszawa 1998, No. 3, p. 18.

${ }^{6}$ M. Gładocha, Social dialogue in collective labor law, Torun 2014, p. 67-68.

7 Judgment of the Supreme Court of 07.12.2012 in case Ref. act II PK $128 / 12$. 
the provisions of Article 59 paragraph 2 of the Constitution grant rights to trade unions, but do not restrict employees in the election of other representatives, and neither do they limit the concept of social dialogue to employers or their organizations and trade unions. Social partners are, in fact, addressed by a more general provision in Article 20 of the Constitution, which does not explicitly mention any subject, but gives a clear indication that social partners base their relations on solidarity, dialogue and cooperation ${ }^{8}$. A similar position was taken by Walerian Sanetra when he stated that the provisions of Article 59 paragraph 2 of the Constitution cannot be understood as excluding the possibility of concluding collective agreements by entities other than those listed therein ${ }^{9}$. It should be recognized that the possibility of concluding an agreement binding on the parties results from the fundamental freedoms of man, and no constitutional or statutory authority is necessary to conclude such an agreement ${ }^{10}$. Consequently, on the employee side, other crew representatives should also be considered as social partners, in addition to the trade unions ${ }^{11}$. Leszek Garlicki, among others, takes a different stance, recognizing that the right provided for in Article 59, paragraph 2 of the Constitution cannot be exercised by any other entity acting as one of the forms of association provided for by the law ${ }^{12}$. When looking for an answer as to who can be a party to a social package (collective package), one should also refer to the provisions of the Labor Code, which do not directly indicate which entities can represent the parties to social dialogue. Thus, considering Community provisions, the Constitution and the Labor Code, the workers' side may be represented either by trade unions, by workers' representation or by the Workers Council.

${ }^{8}$ M. Gładocha, Social dialogue, p. 68.

${ }^{9}$ W. Sanetra, The Constitutional Right to Negotiate, PiZS 1998, No. 12, p. 6.

${ }^{10}$ E. Kieś, "Collective agreements", p. 19.

${ }^{11}$ See Z. Niedbała, M. Piotrowski, Labor Law, ed. Z. Niedbała, Warszawa 2007, p. 335.

${ }^{12}$ L. Garlicki, Marek Zubik (ed.), Constitution of the Republic of Poland. Commentary, volume II, ed. II, Warszawa 2016, Lex 2018; See also: judgment of the Constitutional Tribunal of 2 June 2015, K 1/13, as well as T. Liszcz, Labor Law, Warszawa 2007, p. 516. 
On the employers' side, social agreements may be concluded either by the employer or by employers' organizations. Employers' organizations which may represent employers in the social package are only these organizations which have been established based on the provisions of the Act on Employers' Organizations ${ }^{13}$. On the other hand, there are some doubts as to who can be regarded as an employer entitled to conclude a social package. In the case law of the Supreme Court, related to collective law - which in particular concerns the ability to conclude agreements between social partners the concept of a property employer is adopted, according to which an employer with the capacity to conclude a collective agreement or other agreement is a company, and not its branches, although they are separated organizationally and financially ${ }^{14}$. Moreover, the Supreme Court opposed narrowing down the notion of employers to the definition contained in Article 3 of the Labor Code ${ }^{15}$, basing its position on references to, among others, the provisions of the Constitution. This means that the "working party" (employer in the constitutional sense) may, by virtue of Article 59 paragraph 2 of the Constitution, conclude a collective agreement which will bind the employer as a party to the employment relationship (within the meaning of Article 3 of the Labor Code). The way to determine who is a "constitutional employer" is to use the concept of a "proprietary" ("true", "virtual") employer, in accordance with which, regarding the definition of the working party (social partner - Article 20 of the Constitution) as being entitled to conclude collective packages, it is possible to use the method of "lifting the veil of legal personality". The purpose of this method is to prevent a situation where the real owner, who actually takes over the employee's benefit, abuses the structure of legal personality or the structure of the employer under Article 3 of the Labor Code in order to formally bind the

13 More on: J. Piątkowski, Comment on the Act on Employers' Organizations in Collective Labor Law. Commentary, Warszawa 2016, commentary to art. 1.

${ }^{14}$ K. Jaśkowski, E. Maniewska, Commentary updated to the Labor Code, Lex / el 2018.

${ }^{15}$ Resolution of the Supreme Court of 23.05.2006, III PZP 2/06. 
employee to a dependent entity which is deprived of ownership rights ${ }^{16}$.

A company consisting of more than one employer is capable of concluding social packages; however, a condition for concluding valid social packages containing provisions of a normative nature, specifying the rights and obligations of the parties to the employment relationship, is that such agreements have to be concluded by an employer, two or more employers or an organization of employers ${ }^{17}$. The doctrine recognizes that the "collective" element of such packages refers primarily to the entities entitled to conclude agreements, particularly on the workers' side (trade unions, workers' representatives). However, according to some representatives of science, the concept of collective packages refers not only to the parties to such agreements (contracts), but also to their subject matter. Therefore, pursuant to these doctrines, only the interests or rights and obligations of a particular community, a larger or smaller group of employees, may be the subject of agreements. It is only when these two elements are present that we can classify an agreement as a collective agreement. However, such agreements may not concern individual entities, e.g. the interests or rights of an individual employee. Such agreements do not fall within the concept of a collective agreement, even if the parties to them are entities representing certain collectivities ${ }^{18}$.

Irrespective of their name, however, agreements in collective labor relations are always of the same nature, i.e. regardless of whether the parties are a single employer and a trade union or a larger number of trade unions, such agreements are of a collective nature, as they concern a group of workers represented by trade unions or workers' representatives ${ }^{19}$.

Due to the lack of a statutory definition of collective agreements, both in the labor law literature and in the case law of the Supreme

${ }^{16}$ Resolutions of the Supreme Court of 23.05.2006, III PPL 2/06.

17 Compare the judgment of the Supreme Court from 09.8.2006, III PK 42/06, OSNP 2007, No. 17-18, item 244; TSO 2008.

${ }^{18}$ Z. Salwa, Collective agreements, p. 28

${ }^{19}$ L. Florek, Law and Contract in labor law, Warszawa 2010, s. 226. 
Court, there are difficulties in specifying the contents of the term "collective packages", but "it is generally stated that these are various acts concluded by social partners - representatives of trade unions with employers or their unions, determining the rights and obligations of the parties to the employment relationship. The "collective' nature of these packages refers to the entities entitled to conclude an agreement, as well as its subject matter, which may be the interests or rights and obligations of a particular community. The parties to collective packages, in constitutional terms, are the social partners (Article 20), in particular trade unions, as well as employers and their organizations (Article 59 paragraph 2)"20.

As far as industrial relations are concerned, it is irrelevant whether social packages are based on a law or not (i.e. a division into normative and non-normative agreements), because, as Ludwik Florek points out, it is only a criterion for recognizing such packages as a source of labor law in the area of individual relations ${ }^{21}$.

Taking into account the above considerations, an attempt may be made to define a "social package", on the basis of labor law, as any kind of agreement concluded between an employer or employers' organization and trade unions or workers' representatives, whose purpose is to guarantee specific rights to employees and, possibly, to clarify and specify employees' obligations resulting from sources of higher-ranking labor law. Consequently, as a rule, the subject of social packages consists in broadly understood employee guarantees, correlated with certain obligations of the employer, who is ultimately obliged to fulfill the obligations resulting from such an agreement, and related to an event specified in the agreement (e.g. privatization of the workplace, separation of a specific part of the workplace, change of ownership, merger, division or transformation, reorganization). Starting from the assumption that the possibility of concluding social packages between social dialogue partners at the workplace level results from the Constitution, as well as from international packages and provisions of EU law, the

\footnotetext{
${ }^{20}$ E. Kieś, "Collective agreements", p. 17.

${ }^{21}$ L. Florek, Law and Contract, p. 226.
} 
parties to such packages have considerable freedom in shaping their contents and mutual rights and obligations, while maintaining the principle of employee preference resulting from Article 9 of the Labor Code in conjunction with Article 18 of the Labor Code. Analyzing legal nature of social agreements, we can divide them into normative packages and non-normative agreements, and this division is essential to determine how to interpret the contents of a specific social agreement.

Social packages may be specific sources of labor law, referred to in Article 9 of the Labor Code, or they may be of an obligatory nature only. Therefore, the Supreme Court in its jurisprudence advocates the need to assess social packages in concerto, and the will of the parties to this agreement does not determine whether the social package is a source of labor law ${ }^{22}$. The possibility of recognizing a specific agreement or any other act as an act containing provisions of the labor law within the meaning of Article 9, paragraph 1 of the Labor Code determines whether it meets the criteria specified in these provisions, i.e. whether it is based on the act and defines the rights and obligations of the parties to the employment relationship. This assessment establishes whether a given act from which a party derives its claims is normative (i.e. contains provisions of labor law constituting substantive law) or merely obligatory (i.e. determines only mutual obligations of the parties), and therefore, whether the party bases its claims on substantive law provisions ${ }^{23}$.

A collective normative agreement is an agreement based on a provision of applicable law, from which a relevant standard can be reproduced, including identification of entities authorized to conclude such an agreement, as well as the scope of matters subjected to regulation by these entities ${ }^{24}$.

Divergences, both in case law and in doctrine, concerning normative character of specific collective packages are primarily due

22 Judgment of the Supreme Court of July 19, 2005, II PK 386/04, OSNP 2006 No. 11-12, item 173.

${ }^{23}$ Judgment of the Supreme Court of 8 September 2015, I PK 270/14, Lex 2026876.

${ }^{24}$ E. Kieś, “Collective agreements”, p. 88. 
to different understanding of the requirement that the agreement should be enshrined in law $^{25}$.

In accordance with Article 9 of the Labor Code as the source of labor law, not only the universal, constitutional normative act is recognized, but also acts specific to this branch of law, i.e. collective agreements and other collective agreements based on the act, as well as regulations and statutes. At the same time, literature emphasizes that a normative act constituting a source of law does not have to be entirely devoted to the subject matter of a specific branch of law, but it suffices that only some of its provisions contain regulations concerning this matter ${ }^{26}$. According to Andrzej Swiątkowski, the acts negotiated by social partners (collective agreements), which are not based on the act, do not have the quality of labor law sources ${ }^{27}$. A similar position seems to prevail in the case law of the Supreme Court; in the justification of the judgment of 17 February 2000, the Supreme Court recognized that basing a collective agreement on the act is a prerequisite for regarding such an agreement as a source of labor law ${ }^{28}$. Sources of labor law, within the meaning of Article 9 of the Labor Code, can only include such social agreements which can be concluded pursuant to explicit provisions of the Act (i.e. social agreements which comply with the definition of a collective normative agreement). In its judgment of October 10, 2003, the Supreme Court stated that normative agreements concluded on the basis of the Act of 28 December 1989, on special rules for terminating employment relationships for reasons related to the employer, can only apply to employees in positions subjected to reorganization of the workplace $^{29}$. According to Andrzej Swiątkowski, this view has not

${ }^{25}$ K. Jaśkowski, Labor Code. Volume I. Comment. “Acts accompanying jurisprudence. European labor law with case law”, ed. X. K. Jaśkowski, E. Maniewska, Warszawa 2016, commentary to art. 9.

${ }^{26}$ K. Rączka, Labor Code. Commentary. issue III, M. Gersdorf, M. Raczkowski, K. Rączka, Warszawa 2014, commentary to art. 9 of Labor Code.

27 A. Świątkowski, Labor Code. Commentary, Warszawa 2016, issue 5, Legalis, commentary to art. 9, p. 6.

${ }^{28}$ Judgment of the Supreme Court of 17.02.2000 r., I PKN 541/99.

29 Judgment of the Supreme Court of 10.10.2003 r., I PK 409/02. 
lost its relevance in relation to the Act of 13 March 2003, on special rules for terminating employment relationships with employees for reasons not attributable to employees ${ }^{30}$. The adoption of the above position leads to the conclusion that social agreements, being collective agreements of a non-normative nature (i.e. not based on the act), concluded between the employer and company trade union organizations (employee representatives) are sources of obligations towards employees and can only shape the contents of individual labor relations more favourably than the provisions of labor law ${ }^{31}$.

In several of its judgments, the Supreme Court came to the conclusion that such collective agreements constitute a source of obligations of the employer, who is a party thereto, towards the employees employed by him (i.a. judgment by Supreme Court of 26 May 2000, I PKN 674/99). However, starting from the judgment of 20 June 2006 (judgment in case with ref. symbol of files II PK $323 / 05)$, the Supreme Court is of the opinion that the agreement concluded with trade unions on the basis of Article 3 of the Act of 13 March 2003, on special rules for terminating employment relationships for reasons not attributable to employees, is a source of labor law within the meaning of Article 9 paragraph 1 of the Labor Code, and binds an employer, who can not deviate from its contents when selecting employees for dismissal, or when establishing the order and dates of dismissals.

As Anadrzej Świątkowski indicates, in order to decide whether the normative agreement is based on the act, and therefore whether in legal terms it is a legal act equal to the collective labor agreement, it is necessary to determine whether the intention of the parties to this agreement was to give it the rank of a collective labor agreement, and whether the parties to this agreement refer to any act, other than the Trade Unions Act, as the basis for concluding their agreement $^{32}$. For this reason, according to Andrzej Swiątkowski, agreements based on the Trade Unions Act, which allows union

30 A. Świątkowski, Labor Code. Commentary, p. 6.

${ }^{31}$ Compare ibidem; judgment of the Supreme Court of 17.02.2000 r., I PKN $541 / 99$.

32 A. Świątkowski, Labor Code. Commentary, p. 9. 
organizations to enter into agreements, and on other agreements based on specific laws do not have the nature of labor law ${ }^{33}$. Statutory authorization of an agreement may also be expressed in the compliance of this agreement with the provisions of the Act. Strike and post-strike agreements are accordant with the law on resolving collective disputes. They have the nature of labor law sources within the meaning of Article 9 paragraph 1 of the Labor Code, as they are concluded within the framework of amicable statutory procedures in direct negotiations of the parties to the dispute, or before a mediator ${ }^{34}$. However, collective agreements concluded as part of direct negotiations and during mediations conducted by a mediator have clear statutory support. Such normative agreements can be concluded at any stage of the collective dispute, and also during or at the end of a strike or a protest action ${ }^{35}$.

A social contract, in order to be included in the sources of labor law, must regulate the rights and obligations of employees and employers, while in this context literal understanding of the provisions of Article 9 of the Labor Code would limit the subject of labor law strictly to individual employment relations, and would eliminate from its scope an extensive sphere of relations accompanying individual labor relationships. Therefore, it should be recognized that in Article 9 we are dealing with a certain simplification ${ }^{36}$.

Social agreements which are not based on legal provisions understood in such a way, or do not define the rights and obligations of the parties to the employment relationship, are not agreements of a non-normative nature ${ }^{37}$. Such agreements, according to the Supreme Court, are based on Article 59 paragraph 2 of the Constitution and determine the rights and obligations of parties thereto ${ }^{38}$.

33 Ibidem.

${ }^{34}$ Compare judgement of the Supreme Court of 24.09.2013, III PK 88/12.

35 Judgement of the Supreme Court of 08.07.2014, I PK 312/13.

${ }^{36} \mathrm{~K}$. Rączka, Labor Code. Commentary. issue III, M. Gersdorf, M. Raczkowski, K. Rączka, Warszawa 2014, commentary to art. 9 of Labor Code.

37 Judgement of the Supreme Court of 21.10.2008 r., file III KAS 2/2008, Lex no 2022886.

${ }^{38}$ More on K. Rączka, Labor Code, commentary to art. 9 of Labor Code. 


\section{Rules for interpretation of social normative agreements}

Recognition of normative character of a social contract means that the contents of norms contained in its provisions are decoded in accordance with the rules applicable to interpretation of legal provisions. A contrario, if it is stated that a social contract is of a mandatory nature, the rules for interpretation of declarations of will be applied in determining its contents.

The problem, however, is that normative social agreements are not typical sources of law, and their entry into force is preceded by negotiations of social partners. As such, they are an example of the so-called negotiable way of creating law. Therefore, the doctrine clearly shows the view that one cannot disregard the will of the parties who conclude such collective agreements in the process of interpreting them. Consequently, due to the fact that social contracts arise as a result of an act of agreement between, as it were, two parties, one should refer, to a certain extent, to the rules for interpretation of declarations of will, in particular the interpretation of contracts ${ }^{39}$.

It seems that the position ultimately established in the Supreme Court's jurisprudence, is that in the interpretation of the text (normative contents) of an autonomous source of labor law (Article 9 of the Labor Code) the decisive rules are the rules for interpretation of normative acts, and not those for interpretation of declarations of will, constituting the contents of civil law acts (Article 65 of the Civil Code in relation to Article 300 of the Labor Code $)^{40}$.

At the same time, the Supreme Court allows, on the basis of article 300 of the Labor Code - but only exceptionally and with extreme caution - for appropriate and solely auxiliary application

39 A. Musiał, Collective agreements as a source of labor law, Poznań 2013, p. 196.

${ }^{40}$ Judgement of the Supreme Court of 8.09.2015, I PK 270/14, Lex no. 2026876. 
of Article 65 of the Labor Code in interpreting the provisions contained therein (legal provisions), when the methods of interpretation adopted in relation to the contents of normative acts have failed.

It is therefore assumed that the application of Article 65 of the Civil Code for the interpretation of normative acts, if any wording contained in the provisions of these acts (built to a certain extent on statements of the parties - social partners in the case of collective agreements, collective agreements based on law and social packages, or on unilateral declarations of the employer in the case of remuneration regulations or work regulations determined by unilateral acts of the employer) cannot be explained in any other way than by using methods of interpretation appropriate for interpretation of declarations of intent ${ }^{41}$. In this case, the way in which law is created by means of a law-making agreement (normative agreements), has certain consequences within the area of its interpretation ${ }^{42}$. Such a position of jurisprudence concerning the admissibility of secondary application of the principles of interpretation used for declarations of will in determining the contents of provisions of social contracts is simultaneously approved in the doctrine ${ }^{43}$. There is no doubt in the jurisprudence or in the doctrine that the provisions of collective agreements (including social contracts) of a normative nature are subject to judicial interpretation using all its methods, and not only linguistic interpretation ${ }^{44}$, which means that collective agreements can also be interpreted in a systemic and legal manner, which are undisputed methods of interpreting normative acts.

Consequently, if a social contract is normative in its nature, it is not allowed to interpret its provisions using only the methods of interpretation appropriate for declarations of intent.

${ }^{41}$ Compare judgements: of 08.09.2015, signature of file I PK 270/15, of 20.09.2005, II PK 53/05, LEX no 276239; of 15.03.2006, II PK 143/05, OSNP 2007 no 3-4, item 45; of 5.02.2004, I PK 307/03, OSNP 2004 No 24 item 416; of 19.03.2008, I PK 235/07, OSNP 2009 no 15-16, item 190.

42 A. Musiał, Collective agreements, p. 199.

${ }^{43}$ G. Goździewicz, Gloss to the judgment of the Supreme Court of 22 September 1992, "Przegląd Sądowy" 1993, No. 11-12, item 109.

${ }^{44}$ Compare judgement of the Supreme Court of 26.01.1999, I PKN 439/98, OSNAPiUS 2000, No. 6, item 216. 


\title{
STRESZCZENIE
}

\author{
Umowa społeczna o charakterze normatywnym \\ i jej wykładnia
}

\begin{abstract}
Artykuł skupia się na analizie umów społecznych na poziomie zakładu pracy, ich klasyfikacji z punktu widzenia źródeł prawa pracy. W polskim systemie prawnym nie został ostatecznie przesądzony charakter umów społecznych. W zależności od stron, które zawierają tego rodzaju porozumienia, oraz treści tych porozumień wyróżniamy normatywne i nienormatywne porozumienia społeczne. Charakter prawny porozumienia socjalnego determinuje reżim prawny, który będzie miał do niego zastosowanie, i zasady jego wykładni.
\end{abstract}

Słowa kluczowe: porozumienia zbiorowe; umowa społeczna; umowy zbiorowe; wykładnia

\section{SUMMARY}

Social packages of a normative nature and their interpretation

The article focuses on the analysis of social contracts at the level of the workplace, their classification from the point of view of sources of labor law. In the Polish legal system, the legal nature of social packages has not been determined. Depending on the parties that conclude such agreements and the content of these agreements, we distinguish between normative and non-normative social packages. The legal nature of a social packages determines the legal regime that will apply to it, and the rules for its interpretation.

Keywords: social packages; social contracts; collective agreements; interpretation

\section{BIBLIOGRAPHY}

Florek L., Law and Contract in labor law, Warsaw 2010.

Goździewicz G., Nature of Collective Agreements in Labor Law, Warszawa 1998, No. 3. 
Goździewicz G., Gloss to the judgment of the Supreme Court of 22 September 1992, "Przegląd Sądowy" 1993, No. 11-12.

Gładocha M., Social dialogue in collective labor law, Torun 2014.

Sanetra W, The Constitutional Right to Negotiate, PiZS 1998, No. 12.

Garlicki L., Zubik M. (ed.) Constitution of the Republic of Poland. Commentary, volume II, Warszawa 2016, Lex 2018.

Jaśkowski K., Collective agreements in labor law, in: Individual and collective labor law, L. Florek, ed., Warsaw 2007.

Jaśkowski K., Maniewska E., Commentary updated to the Labor Code, LEX / el 2018.

Jaśkowski K., Labor Code. Volume I. Comment. "Acts accompanying jurisprudence. European labor law with case law”, ed. X. K. Jaśkowski, E. Maniewska, Warszawa 2016.

Kieś E., "Collective agreements worsening the conditions of work performance”, doctoral dissertation, Katowice 2013.

Liszcz T., Labor Law, Warsaw 2007.

Musiał A., Collective agreements as a source of labor law, Poznań 2013.

Niedbała Z., Piotrowski M., Labor Law, ed. Z. Niedbała, Warszawa 2007.

Piątkowski J., Comment on the Act on Employers' Organizations in Collective Labor Law. Commentary, Warszawa 2016.

Rączka K., Labor Code. Commentary. issue III, ed. M. Gersdorf, M. Raczkowski, K. Rączka, Warszawa 2014.

Salwa Z., Collective agreements as a source of labor law, in: W. Sanetra. Labor law. On current issues, Białystok 1999.

Świątkowski A., Labor Code. Commentary, Warszawa 2016, issue 5, Legalis. 
